The University of San Francisco

USF Scholarship: a digital repository @ Gleeson Library |

Geschke Center

1995

\title{
News as a Political Resource: Media Strategies and Political Identity in the U.S. Women's Movement, 1966-1975
}

Bernadette Barker-Plummer

University of San Francisco, barkerplum@usfca.edu

Follow this and additional works at: http://repository.usfca.edu/ms

Part of the Gender, Race, Sexuality, and Ethnicity in Communication Commons, Journalism Studies Commons, Political Science Commons, and the Women's Studies Commons

\section{Recommended Citation}

Barker-Plummer, B. (1995). News as a Political Resource: Media Strategies and Political Identity in the U.S. Women's Movement, 1966-1975. Critical Studies In Mass Communication, 12(3), 306. http://dx.doi.org/10.1080/15295039509366939

This Article is brought to you for free and open access by the College of Arts and Sciences at USF Scholarship: a digital repository @ Gleeson Library | Geschke Center. It has been accepted for inclusion in Media Studies by an authorized administrator of USF Scholarship: a digital repository @ Gleeson Library | Geschke Center. For more information, please contact repository@usfca.edu. 
News as a Political Resource:

Media Strategies and Political Identity in the U.S. Women's Movement. BERNADETTE BARKER-PLUMMER

\section{Published in Critical Studies in Media Communication 1995, 12 (3)}

This paper discusses news as a political resource for social movements. Specifically, the paper elaborates a conceptualization of news as a discursive resource, and suggests a dialogical model for media-movement relationships. The paper then uses this framework to investigate U.S. women's movement groups interactions with news media. I describe how the two "branches" of the women's movement understood news differently and developed quite different and specific strategies which I call media pragmatism and media subversion. The study raises questions not only about what kind

of a resource news might be, and to whom it might be available, but also about the forms of knowledge that can be distributed widely in a society saturated with media "logics."

Social movements, especially the "new" social movements such as the women's, environmental, and peace movements, have come to be seen as important transformative agents in modern societies (Touraine, 1985; Boggs, 1986; Eyerman and Jamison, 1991). In particular, the feminist or women's movement, has been associated with fundamental challenges to traditional or "old" political distinctions, (such as that between public and private concerns), and with subtle, but radical extensions of what can even legitimately be considered a "political" issue (Habermas, 1981; Offe, 1985; Van Zoonen, 1994).

Bernadette Barker-Plummer is Assistant Professor in the Media Studies Program, Department of Communication, University of San Francisco. The author thanks the National Organization for Women for granting access to their historical archive, and Oscar Gandy Jr. for his ongoing support and critique of this project. This work was 
funded by an Annenberg School for Communication Dissertation Research Fellowship. 
But we have less information about how the new movements have created or communicated these new discourses. What are the concrete communication strategies involved in building and diffusing these new political identities? In particular, what role(s) have news media played in the mass communication of new social movement discourses?

In this paper I address some of the theoretical, strategic, and practical problems faced by social movements in their interactions with news media, first through a discussion of news as a political "resource," and then through a case study of how women's movement groups in the U.S. (1966-1975) experienced their relationships with news media.

The general, theoretical importance of news media to social movements seems clear. The way news media represent a social movement can affect their ability to mobilize members, to construct a viable public identity, or to build a public policy agenda (Gitlin, 1980; Hackett, 1991; Molotch, 1988). Indeed, the perception of a movement that most individuals are likely to hold is the movement's "public identity," and this is itself the outcome of media-movement interaction (Van Zoonen, 1992). However, we have less specific information about the ways in which these general processes work out (or not) for particular social movements in specific historical circumstances. For example, how have movement strategists themselves understood their interactions with media? What strategies have they developed to try to "use" media as a movement resource, and what has news access "cost" them? What kind of a resource has news been for specific social movements and why?

In this paper I address these questions to the groups that were active in the early years of the second wave women's movement in the United States (1966-1975). I describe how the two "branches" of the women's movement understood news differently and developed quite different and specific strategies to deal with news media. These strategies, which I call media pragmatism and media subversion, were in turn related to 
the groups' available resources, their media skills, and their political identities more generally. The paper draws on the historical papers of the National Organization for Women, on accounts of the early movement by activists and historians, and on accounts of covering the movement by women journalists. ${ }^{1}$

\section{THEORY: NEWS AS A POLITICAL RESOURCE}

For the most part, studies of news as a political resource have focused on institutional, usually state, but sometimes also corporate sources. Gandy (1982, p. 198), for example, has argued convincingly for the importance of information as a political resource for both public and private organizations. Those organizations that can produce and distribute reliable information to others are seen to be "subsidizing" decision-making in their favor. Because such information is the raw material of news making, organizations who make information available to journalists are "subsidizing" the construction of news stories in their interests. As Gandy explains, "An information subsidy increases the demand for certain information by lowering its price to the consumer... The journalist's costs of producing news are reduced through a variety of techniques utilized by sources to manage the information market."

In this framework, news is a political resource, first, because access to information at all is directly related to other material resources (such as the labor, skills and money to create or process it). Secondly, providing information to others structures their decision-making (Gandy, 1982, p. 198).

But news is not only a channel for the transmission of information. It is also a complex, knowledge-producing system in itself, with its own conventions, practices and "logics" (Van Dijk, 1988; Hartley, 1982; Altheide and Snow, 1979). In particular, news discourse is a privileged form of knowledge in political life. It is generally considered to be an authoritative version of reality, a way of knowing associated with high levels of cultural legitimacy. As such, news offers sources another form of power beyond the 
chance to distribute interested information; it offers membership in a group of "knowers." It is this association with authority that, according to Ericson, Baranek and Chan (1989, pp. 3-4), makes news a form of cultural capital for its regular sources:

News is a representation of authority. In the contemporary knowledge society news represents who are the authorized knowers and what are their authoritative versions of reality.... It indicates who is in possession of knowledge as "cultural capital," and thereby articulates who are members of the "new class" who derive their labour and property membership from the production, distribution and administration of knowledge.

In this knowledge/power framework, representation in news -- in fact a particular kind of representation, voice as opposed to coverage -- confers authority on the source, because news itself has come to hold a special place as an authoritative version of reality.

News is a political resource, then, in that it is a modality of power. News voice translates into legitimacy in the knowledge system for the speaker, and news' distributive capacity allows the speaker to communicate that knowledge widely, and so structure the public information environment. In media-saturated societies, voice in the news is a key part of making one's "account count" in the public sphere .

\section{News as a Social Movement Resource}

But how does such a relationship work out for social movements? The organizations that Ericson et al. (1989) and Gandy (1982) refer to are usually either state or corporate bureaucratic organizations, who have access to resources, and to whom legitimacy in the existing political configuration is a clear goal. Yet even for these powerful sources, access to news, and especially voice in the news, constitutes a daily struggle (Ericson et al., 1989; Schlesinger, 1990).

What difference does it make when sources are challenging or critical, when they are under-resourced, or when their knowledge is new or in forms that may not merge well 
with traditional news forms? Can social movements be understood as sources in the same way that institutional sources are? Is news likely to be a form of cultural capital for social movements? And, if so, is it one that they can afford?

Based on his case study of Students for a Democratic Society (SDS), Gitlin (1980, p. 281), of course, has argued forcefully that news will never adequately carry social movement discourses because of the economic, organizational, and ideological connections that news organizations and news discourses have to dominant power relations in society. Though movements will be attracted to commercial news media as a way of "getting the word out," Gitlin concludes that news media are likely to cover them and their concerns in ways that will be counter-productive to critical social change. He argues that commercial media, through their professional "routines" and practices -which are themselves embedded in capitalist and profit-oriented ideologies -- will serve to "frame" critical social movements and their activities in trivializing or marginalizing ways. In this hegemonic model, news media are central players in the systematic suppression of critical voices:

....an opposition movement is caught in a fundamental and inescapable dilemma. If it stands outside the dominant realm of discourse, it is liable to be consigned to marginality and political irrelevance; its issues are domesticated, it's deeper challenge to the social order sealed off, trivialized and contained. If, on the other hand it plays by conventional political rules in order to acquire an image of credibility -- if, that is, its leaders are wellmannered, its actions well-ordered, and it's slogans specific and "reasonable" -- it is liable to be assimilated into the hegemonic political world view; it comes to be identified with narrow (if important) reform issues, and its oppositional edge is blunted. 
But Gitlin's conclusions may be too much too soon. SDS was one, early, and relatively short-lived organization whose own development of media strategies was quite limited. But more importantly, the reform or revolution dichotomy that Gitlin invokes here, in which movements will either be marginalized if they are radical or incorporated if they are liberal, raises further difficulties. This approach begs the question of how we come to know what movements "are" at all. As Melucci (1985, p. 792) has observed, though historians and observers often talk about "movements" as if they were already constituted entities, who act in coherent ways, in fact "movements" are social constructions that are created and maintained through communication practices across time. And one of the forces with which movements interact in forming identities, are media themselves. As Van Zoonen (1994) has suggested, it is not really a question of whether news covers a "given" (liberal or radical) social movement in a "true" way or not, but of how the various "identities," strategies and organizational practices of a movement interact with the complex, though structured, selection "rules" of news media to create particular outcomes.

Perhaps the most limiting aspect of a closed hegemonic model such as Gitlin suggests, is that it seems to deny the reflexivity or strategic agency on the part of social movement actors themselves to learn about and strategically use dominant systems and discourses -- in this case journalistic routines and practices -- as resources themselves. ${ }^{2}$ Movements can, potentially at least, learn about news organizations' routines, practices and discursive logics, and take part in framing themselves.

Giddens (1984) has suggested that this kind of reflexivity -- the ability to access and discursively use the "rules" as resources -- is itself a fundamental aspect of human agency, and one that challenges deterministic explanations for human practices in many different circumstances. In the context of social movements, media and social change, this reflexivity and strategic use of constraints by movements may sometimes make news discourse a movement resource. Indeed in a more recent study of movement-media 
interaction, for example, Ryan (1991) suggests that through the reflexive and strategic use of the very journalistic routines that Gitlin credits with destroying the student movement, "challenging" groups can begin to strategically "frame" themselves in newsworthy and culturally resonant ways. ${ }^{3}$

A radical/reformist framework gives us only two "outcome" possibilities, (trivialization or incorporation) for what is a complex, communicative interaction between two sets of organizations and discourses across time. But social change, especially ideological change, is never such an all or nothing process. ${ }^{4}$ As Boggs (1986, p. 4) has expressed it, strategic communication of new knowledges, of new ways of knowing, and of alternative articulations of social relations by social movements may have subtle and unintended effects:

...[T]he fact that they [the new social movements] have nowhere overturned the status quo should not obscure their historical importance in posing new issues, shaping consciousness, and opening new areas of political discourse. Indeed, many time-honored debates have already been fundamentally recast in both substance and tone.

\section{Towards a Dialogical Model}

The media-movement relationship can perhaps best be characterized as dialogical -- that is, as an interactive, reflexive, relationship that takes place over time. It is a relationship in which both media workers and movement strategists are knowledgeable, strategic agents, seeking to learn about and use each other's discourse. Such learning, and the incorporation of that knowledge into future interactions, can be seen as a form of strategic interaction (cf. Goffman, 1969; Habermas, 1984). ${ }^{5}$

Understanding the media-movement relationship as a dialogical one, opens up our understanding of media and movements from one of "coverage" -- in which news 
representations of social movements are (implicitly at least) compared to some ideal representation of reality -- into one in which two sets of actors are seen to be working within constraints to create and recreate different constructions of reality. It also focuses our attention on the medium of such relationships: information, knowledge and meanings.

Seeing the media-movement relationship as two-way does not preclude an imbalanced interaction, nor deny that one organization holds more power than the other. Movements are always likely to be less well resourced than either news organizations or the other corporate or state sources with which they compete for news access. Becoming involved in interaction with news media at all, will certainly cost resources that movements can ill afford. And, perhaps most critically, it is also likely to involve ideological costs -- framing a critical discourse successfully for news consumption may mean re-framing it in crucial ways. But to say that a relationship is difficult, complex, subtle, and unbalanced is not to say that its outcomes are inevitable. As Hackett (1991, p. 281) notes in his conclusion to a study of the Canadian press and peace movement, using news may be an uphill battle for challengers but its outcomes are by no means predetermined: "The press is not a level playing field, but sometimes it is possible, even playing uphill, to score points, to win a match, and perhaps occasionally even to redefine the rules of the game.

When we see movements and media engaged in strategic interaction, or dialogical struggle, instead of inquiring how a movement is covered by the news organizations, we can ask: How do movement strategists and journalists interact? How have movement organizations understood news as a resource and how have they experienced its constraints, both in terms of the "cost" of accessing news and in constraining their identity formation? What strategies have they developed to control their interactions with news media and how have those strategies fared in interaction with news media routines and processes? In short, what has worked and what hasn't? A dialogical understanding 
may produce critical or strategic knowledge, knowledge that may be used to produce change.

In the next section, I address some of these strategic questions to the concrete historical experiences of different groups in the U. S. women's movement 1966-1975. 


\section{PRACTICE: MEDIA STRATEGIES IN THE U.S. WOMEN'S MOVEMENT}

The early women's movement in the United States was made up of a loosely organized and highly differentiated set of individuals, texts and organizations. Many different kinds of women's groups formed and reformed, organizing around various feminist principles and practices. Some of these groups were in contact with each other, others operated only in their own locality (Freeman, 1975; Echols, 1989).

Freeman (1975, p. 50), an early movement activist and historian, has suggested that we can best understand the complexity of the early women's movement if we think of it as breaking down very generally into a "younger" and an "older" branch. ${ }^{6}$ The "older" branch of the movement was made up of national organizations, such as the National Organization for Women (NOW), National Women's Political Caucus (NWPC), Women's Equity Action League (WEAL), and so on. They tended to focus on political action in the public domain, to be organized around a democratically elected Board and to have some paid staff. NOW had both a national office and a coordinated set of local "chapters" in towns and cities around the country.

Generally speaking, in the early years the older branch saw themselves as pressuring the political system and fighting to bring women into the power structure. NOW, for example, in its organizing statement said that it had formed in 1966 in order to "take action to bring women into full participation in the mainstream of American society now, exercising all the privileges and responsibilities thereof in truly equal partnership with men."’

The "younger" branch of the movement was a more loosely organized plethora of different, often local, groups whose activities varied from consciousness-raising to political "zaps" and protests, and who experimented with alternative forms of association. To the younger groups, personal transformation was as important as public change and they tried to embody their politics in practice through problematizing issues of hierarchy, specialization, and routinization. They tried to invent new forms of association which 
were leaderless and "structureless" because they were concerned that any form of traditional organization or leadership would "mimic" patriarchal power structures. They were almost always women-only groups.(Joreen, 1973, Freeman, 1975; Koedt et al. 1973, Evans, 1979).

These general differences in articulations of feminism and in organizational logics were reflected in the communication practices and media relations of the two "branches." NOW held a pragmatic and strategic view of media in which they sought to learn about and use media as a political tool. The younger branch had more complicated and antagonistic relations with journalists in which they tried to make news workers conform to their organizational and political identities.

Both of these positions required that feminist activists understand news media -whether to subvert it or to use it -- and both branches spent considerable time and energy on the "question of media." I call these two different media strategies media pragmatism and media subversion.

\section{Media Pragmatists: The National Organization for Women}

The "older" branch, as exemplified by the National Organization for Women, saw themselves as spokespersons for the movement, as a sort of vanguard who could speak to media and policy makers on behalf of a group called "women." They were mostly women who had worked in traditional political organizations before -- many of them had been part of Kennedy's Presidential Commission on the Status of Women -- and they were comfortable with themselves in the role of "leaders" of a civil rights organization who could speak "for" its more general membership : "As a militant civil rights organization, NOW must speak out on news events related to the drive for equality between men and women." 8

From the beginning NOW saw media, especially the national, elite, news media, as a powerful movement resource. They sought to use news media to mobilize new 
members and to win public approval, while also giving the public an "honest" picture of the movement:

Our major goals in press relations are threefold:

1. To build NOW and the movement by reaching and recruiting prospective adherents.

2. To win political and community support for our goals.

3. To give the general public an honest picture of the Feminist Movement. ${ }^{9}$

If there is a hint of naiveté in this statement that they could use media to present an "honest" picture of the movement, it was not born of ignorance. NOW's national leadership was well versed in media skills from the beginning. The early Board members who were not lawyers were often communications professionals, such as writers, public relations specialists or journalists, and after the first few struggling years the organization had paid information staff.

\section{Media Kits}

Through the development of "Media Kits" in which they laid out strategies for dealing with news media, these national leaders sought to make the whole organization media-literate was. The kits were then distributed to the local chapters of the organization for use by local feminist activists. In this way the organization's national or central resources -- professional communications specialists on the board and paid public information workers -- was distributed back to the localities.

Advice in the kits ranged from the pedantic to the sophisticated, from suggesting that local activists prepare a handout so that reporters get the facts straight, to advising that cake and coffee are optional at press conferences . In general they stressed understanding both the day-to-day practices of journalists and also understanding how 
news discourse was structured, through trying to predict what would make something "newsworthy":

The beginning of a survey of employment practices may or may not be news -- but the conclusion will be. A charge that some company discriminates against a woman may or may not be news -- but the announcement that an EEOC complaint has been filed will be. A speaker

at a

meeting will not be news - unless she or he is a well known personality. In the final analysis it's a trial and error game..$^{10}$

The media kits suggested that local chapters should designate press representatives whose job would be to get to know reporters and to coordinate media relations, and urged local activists to "think of yourself as a kind of editor" when planning events and activities. ${ }^{11}$

In addition to these kits for local activists, the central communications workers also produced many different kinds of information packages for reporters, sent out press releases and also at one point attempted an ongoing NOW News Service. ${ }^{12}$ These "backgrounder" packages had direct advocacy purposes -- NOW hoped to encourage coverage of issues and events that they thought were important -- but they also carried much general (and useful) background information and research representing significant work on NOW's part. ${ }^{13}$

\section{National NOW and Women Reporters}

NOW were involved in relationships with many different kinds of media organizations. They tried, and succeeded, for example, in placing speakers on major talkshows, and they had ongoing relationships with editors and writers at women's magazines. But news media, especially elite national media, were always an important target . 
At the national level one of NOW's key strategies was to try to build a network of "women's issue" reporters from among sympathetic women on the elite press. There was a small cadre of such reporters, who from the early days recognized the importance of the movement -- at least it's more "liberal" or equality-type concerns -- as legitimate. NOW media strategists kept these reporters "up to date" and connected to what the movement was doing, by sending them information and research, by setting up interviews with the movement's leaders, and even taking them to lunch.

Building relationships with journalists and providing information for them is of course what all sources try to do, but NOW seemed to also be concerned with the position of women reporters in their own institutions, recognizing that in order for them to do any stories on the movement, they would need to be supported from outside with reliable information and friendly sources. In fact NOW often saw themselves as being in the business of educating or "raising the consciousness" of reporters as much as any other group of women. ${ }^{14}$ The women journalists who comprised NOW's informal "women's issue" beat worked for such prestigious news outlets as The New York Times and The Washington Post. However, they often had to fight with their editors to cover the movement, or else they ended up covering women's politics in their spare time or on a "volunteer basis" after work (Robertson 1992, p. 15).

For the most part editors at the elite press took a long time to be persuaded that women's politics were really “news.” Peggy Simpson (1979, p. 21), for example, recalls her early covering of the movement as one in which her attempts to become an expert were constantly thwarted by lack of support and resources from editors: "Clearly my editors and other media executives did not consider the women's political movement to be a bona fide story meriting continuing and expert coverage. Other reporters were getting the same signal." Marilyn Goldstein (North, 1970, p. 105) who wrote a series on the movement in its early days for Newsday, also remembers that her editor cut out much 
of her explanatory material on the movement, and told her to "find an authority who'll say this is all a crock of shit."

Despite these setbacks, it was mostly this small group of women who wrote what little news there was about the movement in its early days. Though these women were sympathetic to women's issues as news, they did not always consider themselves feminists. As Peggy Simpson (1979, p. 21) recalls: "I thought of myself not as a feminist but as a reporter covering a good story that for some reason almost all of my male colleagues had ignored."

The women were on one level simply acting like journalists -- developing a group of "expert" sources. But they were at least able to see women's issue news as news, and NOW as a credible source, which was more than their male colleagues or editors had done. Whether or not the women reporters felt themselves to be feminists, then, they brought their professional judgment to bear on feminist information. They were able to use the routines of journalism -- and perhaps also to use the rhetorical strategy of a "good" story -- to cover issues that were also important to them personally.

NOW's role here was as a provider of alternative knowledge, as the research and production department for the women reporters. Without a supportive "expert" source network these women might never have convinced their editors that women's issues were news at all. As Simpson (1979, p. 20) points out when remembering her early work life in Texas, if research and arguments are not made available to journalists by sources they are unlikely to come up with it themselves:

At that time I had not reported on any major elements of the early women's liberation marches and had never met anyone who called herself a feminist.

I did know a lobbyist from the Texas chapter of Business and Professional Women who was unsuccessfully trying to get a state Equal Rights 
Amendment passed. She never approached me, during my two terms covering the Texas Legislature, and I never called her, so a persuasive

state

senator easily convinced me that women would be in terrible straits if

Texas

protective labor laws and community property laws were altered by the ERA.

Besides supplying journalists with information, NOW also monitored much of the press coverage of the movement and its concern. They would compile updates on how the organization and its issues were being represented and use that information to restructure their media strategies or public identity. A typical example of such monitoring took place after the NOW national convention in 1973 when the NOW Public Information Office collected coverage from the national press and asked all chapters to send in their local coverage for analysis. The resulting analysis was published within the organization and became part of future strategizing efforts. ${ }^{15}$ It is this kind of reflexive process, in which an organization can analyze its own representation and so shift its communication strategies, that illustrates the essentially dialogical nature of the mediamovement relationship.

\section{"Costs" and "Benefits" of Media Pragmatism}

To some extent, NOW succeeded in becoming one of the key sources in an informal "women's issue" beat in Washington in the seventies (Simpson, 1979; Robertson, 1992). In early stories about "women's rights" issues and legislation or policy on discrimination, NOW was often the feminist group cited.

But this embedding of news discourse conventions into their articulations also "cost" them not only in skills, labor and time, but also in the range of topics they could comfortably address. They had to be vigilant in all media interactions. Knowing what 
would set off media meant that they would try to preempt journalists. This attempt to control communication to media -- though not untypical of organizations in successful interaction with journalists -- was problematic for a social movement. ${ }^{16}$ As a part of a new and critical movement, NOW was often criticized inside the movement for being too cautious. In particular early NOW leaders were very sensitive to questions and debate on sexuality :

[W]e do know that questions involving the sexual and social relationships between men and women are especially sensitive and especially

susceptible

to ridicule by the press. Special caution must be observed in statements that

go beyond official NOW policy in this area. ${ }^{17}$

Ironically of course, the "social and sexual relationships between men and women" -- and indeed the social and sexual relationships between women and women -were, and remain, at the heart of feminist concerns. To restrict talk on such issues was to opt out of an important part of the domain of personal politics that has been the hallmark of the feminist movement. NOW gained a reputation in its early years in the movement as anti-lesbian because recognizing or talking about lesbianism would cause them "image problems." Rita Mae Brown described NOW's position on lesbianism in her resignation from the organization in 1970 (cited in Phelan, 1989, p. 38):

Lesbianism is the one word that can cause the Executive Committee a collective heart attack. This issue is dismissed as unimportant, too dangerous to contemplate, divisive or whatever excuse could be dredged

up

from their repression. The prevailing attitude is ... "Suppose they (notice the word, they) flock to us in droves? How horrible. After all think of our image." 
Later, especially after 1975, as the younger branch groups disappeared, NOW itself became the site for serious struggle over what the public identity of feminism would be in the United States and as a consequence became much more open to, and representative of, women of all feminist identities. ${ }^{18}$

It is difficult to say, exactly, of course, how much of NOW's discursive choices were affected by media logics. It is possible that NOW's original leaders shared certain values with the mostly white, mostly middle class professional women journalists with whom they interacted anyway. To the professional middle class women who made up NOW's early membership and board, liberal news discourse conventions may not have seemed so unusual. And in some ways the aims of NOW and of media coincided. NOW saw itself as an action group and the media's focus on their activities rather than their ideology was no surprise to them. But it is clear that for NOW as an organization media was a central concern. From the beginning they invested resources and skills in media as an important mobilizing tool. They set out to "use" it and in their own eyes it was often a useful resource.

\section{Media Subversives: The Younger Branch}

The "younger" branch had more antagonistic relations with news media. Their relationship with reporters was more likely to be hostile than helpful because they associated news with other political institutions that had marginalized women's concerns (Freeman, 1975; North, 1970).

For the "younger" movement groups, media became intertwined with more general issues of power and representation within their organizations. Issues of who should or could speak FOR the movement and who should be seen [if anybody] as leaders of the movement were issues that were always problematic for the movement, but which interaction with media exacerbated. In their attempts to deconstruct patriarchal systems, younger movement groups (such as New York Radical Women, Redstockings, 
Women's Liberation) often equated bureaucratization or specialization with patriarchal forms of organization and refused to have either designated leaders, or spokespersons, preferring to have a "structureless" organization in which each individual would "speak for herself" (Joreen, 1973).

These organizational structures made the search for news sources difficult for journalists. The same search for authoritative sources that women journalists had been able to satisfy by talking to NOW, led journalists into trouble with the younger movement groups. As a women's liberation member said to reporter Sandie North (1970, p. 105), when she tried to find a movement spokesperson, "Any woman working in the media can write about her own oppression as a woman, so why should the press need to talk to any of us?"

However, asking a journalist to speak in her own voice in the 1970s was not particularly helpful advice. There were still few women reporters in the major news organizations, and rather than invent new forms of journalism, these women were often expected to satisfy more rigid standards of sourcing than their male colleagues because of sexist perceptions of women as less competent journalists (Hoffman, 1970).

Neither could a journalist realistically take the other option and speak to everyone in the movement or even to everyone in an organization, and just as reporters did with the student movement, journalists sought out and made their own "leaders" of the liberation movement. As Echols (1989, p. 209) notes, these strategies often had unintended consequences: "Ironically, the movement's self-imposed silence empowered the media, allowing them to choose Gloria Steinham -- a talented journalist sympathetic to feminism, but a virtual unknown in movement circles -- as a movement spokesperson."

Whereas NOW had built into their organizational identity the role of spokesperson, the younger movement could not easily compromise on the issue. Central to their critique of patriarchal ways of knowing and representing others, was their belief in the importance of knowledge gained from personal experience. They had seen too 
often in the past how women had been spoken "about" and "for" by male voices. In particular they valued personal testimony or experiences of oppression that had not been able to be spoken before. By asking reporters to listen to a wide variety of women, or indeed to listen to themselves, they were expressing a key tenet of their feminism, but it was not one that fit easily with news conventions.

\section{Women Only}

The conflict between the younger groups' articulations of feminism and news discourse conventions manifested itself again quite clearly when women's groups began a policy of speaking only to women reporters and excluding male journalists from their events and conferences. Starting at the 1968 Miss America protest -- when women demonstrators from New York Radical Women (NYRW) simply refused to speak to male reporters or to answer them explaining, "Why should we talk with them? It's impossible for men to understand" -- this policy soon became an informal rule among many women's groups.

The women's groups involved hoped that their separatist strategy would make it easier to deal with the press, (which would result in better coverage), and that it might also force the news media to hire more women journalists. They had seen how the Civil Rights Movement had forced editors to employ more African-American journalists and thought that they would do the same in order to cover the women's liberation movement (Freeman, 1975, p. 113).

As a group who had chosen their name, The National Organization "for" Women, deliberately so that men could also be a part of ending sexism, NOW were unlikely to adopt such a policy. But the policy was quite an accurate reflection of some implicit essentialisms in the younger movement . The younger groups seemed to believe that women reporters would somehow, naturally, be more sympathetic because they were women. But they failed to take into account that women reporters also followed the conventions and "logics" of news. 
The younger branch's refusal to embed any media logics into their communications sometimes extended into outright hostility where women sabotaged attempts to "cover" movement events because they were suspicious of how that coverage would turn out. Male reporters were often harassed and sometimes subjected to physical abuse, though, ironically, it didn't seem to cure them of their sexism (North, 1970, p. 105):

"Get the pigs out!" was the rally cry for a contingent of women who last fall drove Doug Johnson, a WABC-TV correspondent away from a Women's Lib meeting. "One of the girls smashed my microphone. She was rabid, but she was a lovely little thing." But even sympathetic reporters found the younger movement difficult to cover. Marlene Sanders of ABC-TV (cited in North, 1970. p. 106), remembers the movement as a very hard story to get, and that covering the younger movement meant "fighting everybody, everywhere, all the time.... I am in real agreement with the Women's Liberation front and they're oppressing me."

Emblematic of the news-movement relationship in the early years was the nonstory of how women liberationists had burned their bras. News outlets all over the country reported and re-reported on how women in demonstrations had burned their bras as a symbol of protest against femininity. The (in)famous bras were of course never actually burned. Restrictive underwear including corsets and bras were thrown into a "freedom trashcan" at the 1968 Miss America Pageant in 1968, but they were never set on fire except in reporters' imagination (Martin, 1971; Klemsrud, 1974). The creation by media of burning bras became a shared grievance across all movement groups. Joanne Foley Martin (Martin, 1971, p. 11), a NOW activist, explains how such fabrication alienated even the media pragmatists :

The women's liberation movement and bra destruction have nothing to do with each other. No one in the women's liberation movement has burned 
or otherwise mutilated a bra. At least not in public.... This sort of publicity if puzzling and upsetting to those of us who joined the movement because of our concerns about serious problems of sex discrimination.

\section{Controlling Communication From Within}

The debate over the role of media in the younger movement reached a crisis at the 1970 Congress to Unite Women where a proposal from the Class Workshop on "What can we do about the media?" advocated publicly censuring some women who had become media "stars" and enforcing strict movement rules to cover future interaction with media (Echols, 1989, p. 208):

1. Anyone who appears in the media has to be drawn by lot from her group... The lot is to be rotating. None is to participate in the media

alone...

2. Women's Liberation is becoming popular enough that they need us as much as we need them. We can and must dictate our terms to them;

present

prepared statements and refuse to give personal information. From now on anyone who refuses to follow this policy must be assumed to be doing so for her own personal aggrandizement.

3. No member of the group can appear as an independent feminist whether for fame or for money... We condemn Susan Brownmiller and Lucy Komisar [two feminists who had written extensively on the movement] for seeking to rise to fame on the back of the women's movement by

publishing

articles in the establishment press. 
The attempt to "censure" these women (and evict them from the movement) ultimately failed when the resolution was voted down, but it does indicate a strong response within the movement to control communication to media. Although they manifested it in different ways, the younger movement, like the older branch, were centrally concerned with internal control of movement communications to media. For the younger branch that concern was about who could speak, whereas with NOW it concerned what could be spoken about.

\section{Costs and Benefits of Media Subversion}

The younger branch of the movement seem to have recognized early on that their practices and philosophies were not going to merge well with news routines, and they set about making policies that they hoped would counteract that tendency. At meetings they would insist that only women reporters come, and that a diverse panel of women be talked to. On one occasion The Feminists even had a woman reporter sign a \$1,000 promissory note that would be forfeited if her article mentioned particular individuals (North, 1970, p. 105). But these policies did not take into account the restrictions under which journalists, even sympathetic women journalists, worked. The younger group's demands often seemed unreasonable and even paranoid to journalists, such that they would think twice about doing stories on the movement (North, 1970).

The clash was to some extent inevitable; the purposes and "logics" of journalists and activists were in fundamental conflict. To the "younger" branch, the media was an intrusion into their community and a problem whose demands could not be met without some conflict with their own understandings and articulations of feminism. To embed in their discourse journalistic ideas of "balance" or neutrality, or to have one voice and experience stand in for many would have meant undermining their own politics. But neither could the media be ignored because they would simply re-create the movement 
from inadequate information. The relationship became one of avoidance, hostility or brave, but unrealistic, attempts to change media practices.

\section{(IN)CONCLUSION: NEWS AS A POLITICAL RESOURCE, NEWS AS CULTURAL CAPITAL}

The "older" and "younger" branches of the movement had quite different interactions with journalists and quite different understandings of news as a political resource.

NOW had a pragmatic and strategic relationship with news media; they tried to build relationships with women journalists, and their activities were usually organized with an eye to media. Indeed, if local activists actually followed the advice of NOW's media "kits," then media "logic" was encoded into their planning and communications from the beginning.

NOW's approach did get the organization into the news columns. In the elite press they became "expert sources" in an informal and narrow beat of "women's issues." They became one of the key voices in the building of an informal "women's issue" policy agenda. But their media-centric strategizing cost them in resources and time, as well as in freedom to articulate more inclusive feminism(s). Being media-savvy meant encoding news discourse categories and limitations into their own articulations.

The younger branch had a more fraught relationship with news. Their attempts to produce egalitarian organizational forms ran counter to journalist's search for "leaders" to whom they could attribute statements about the movement. And their focus on "personal politics" (Evans, 1979), on issues of power and sexuality, was sometimes difficult for reporters and editors to understand as politics at all (Simpson, 1979).

The outcome of the younger branch's chosen identity and strategies is less clear.

Early and partial accounts of coverage of the movement suggest that in the early years the younger movement was ridiculed or ignored ${ }^{19}$ But it is clear that the younger movement 
groups understood news, not as a resource as NOW had, but as a problematic part of the system they opposed overall.

These two quite different experiences of the movement "branches" raise questions not only about what kind of a resource news might be, or to whom it may be available, but more generally about the forms of knowledge that can be communicated widely in a media saturated society.

Clearly a group's media strategies are tied to its political identity more generally. But we cannot conclude, as Gitlin (1980, p. 281) might, that because the younger branch was "radical" they were represented in a marginalizing way, or that because NOW were "liberal" their issues were incorporated. Rather, the different political identities and organizational forms of the two branches of the movements, prestructured their possible choices in interactions with journalists. Their media strategies intervened between any "given" identity and any "given" representation.

What is at work here is a subtle discursive process of struggle over forms of knowledge, in particular over what forms of knowledge can be "carried" adequately by news, and so make it into the public sphere. NOW decided that their concerns could be expressed in news discourse and often restricted their own discourse so that it would be carried by news. The younger branch found that their non-hierarchical, focus on issues of "personal politics" would not "carry."

Ericson et al.'s (1989) conceptualization of news as a form of authority or "cultural capital" seems to be at work here for NOW. They saw access to mainstream news as an important goal that would get their issues and concerns out to the public, while at the same time gaining them legitimacy as a spokesperson for feminism in the public sphere. But for the younger movement -- who were at best ambivalent about the value of legitimacy in the public sphere -- news was not a form of "capital." They saw the media's representation of them as a form of power, but they often chose for themselves 
another form of capital -- "counter-cultural capital" -- which gained them power within the movement rather than outside.

News, like signification, or knowledge more generally, is a resource, then, but it is a resource whose strategic use requires that sources articulate their experiences within its terms. Like other forms of discourse, news is a system of meaning, one that comes with its own encoded and implicit assumptions about reality. Using that discourse constrains what it is possible to say.

This conclusion raises two different types of questions for social movements and other critical sources. First, is the question of whether movements can use news discourse as it currently exists for their own purposes. As this case study has suggested, the answer to this question involves calculations about resource investments and about the ideological constraints of being "translated" through news that can only be answered within a specific interactive context by concrete historical actors. We need many more examples of such strategic interactions.

The second type of question for movements and other critical sources that the discussion raises is more historical. It asks -- can interacting with news change news itself? Because news discourse $i s$ a system of meaning, it is also flexible and shifting, and its strategic use by critical sources may result in changing the discourse itself. So that even if short term interactions are frustrating, there may be longer term gains for critical sources. ${ }^{20}$

Answering these questions requires that we know much more about how specific movement organizations and discourses have fared in interaction with news, and how those interactions change both sets of actors. Such interactions are likely to be highly complex and are certainly historically contingent. But it is only through looking at many such instances that we can generalize and begin to adequately theorize media-movement interactions and to understand news as a political resource (or not) for social change. This case study is offered as a contribution to that growing critical literature. 


\section{REFERENCES}

Altheide, D. \& Snow, R.P. (1979). Media logic. Newbury Park, CA: Sage.

Boggs, C. (1986). Social movements and political power. Philadelphia, PA: Temple University Press

Bourdieu, P. (1977). Outline of a theory of practice. New York: Cambridge University Press

Echols, A. (1989). Daring to be bad. Radical feminism in America, 1967-1975. Minneapolis: University of Minnesota Press

Ericson, R., Baranek. P. \& Chan, C. (1989). Negotiating control: A study of news sources. Toronto: University of Toronto Press

Evans, S. (1979). Personal politics. The roots of women's liberation in the civil rights movement and the new left. New York: Random House

Eyerman, R. \& Jamison, A.. (1991). Social movements: A cognitive approach. College Park, PA: Pennsylvania State University Press

Freeman, J. (1975). The Politics of Women's Liberation. New York: Longmann

Gandy, O. (1982). Beyond agenda-setting. Information subsidies and public policy. Norwood, NJ: Ablex 
Gans, H. (1980). Deciding what's news. New York: Vintage Books

Giddens, A. (1979). Central problems in social theory. Berkeley, CA: University of California Press

Giddens, A. (1984). The constitution of society. Berkeley, California: University of California Press

Gitlin, T. (1980). The whole world is watching. Media in the making and unmaking of the new left. Berkeley, CA: University of California Press

Goffman, E. (1969). Strategic interaction. Philadelphia, PA: University of Pennsylvania Press.

Habermas, J. (1981). New social movements. Telos 49 (Fall 1981):33-38.

Hackett, R. A. (1991). News and dissent: The press and the politics of peace in Canada. Norwood, NJ: Ablex

Hartley, J. (1982). Understanding news. London: Routledge

Hoffman, E. (1970) Women in the Newsroom. Columbia Journalism Review Winter 1970-1971: 53-55

Hole, J. \& Levine, E. (1971). Rebirth of feminism. New York: Quadrangle Books. 
Joreen (Freeman, J.). (1973). The tyranny of structurelessness. In Koedt, A., Levine, E. \& Rapone, A. (Eds.), Radical feminism. (pp. 285-300). New York: Quadrangle Books.

Klemsrud, J. (1974, September 8) Can feminists upstage Miss America? The New York Times , p. 58

Koedt, A., Levine, E. \& Rapone, A. (Eds.), (1973). Radical feminism..

New York: Quadrangle Books.

Martin, J. F. (1971). Confessions of a non-bra-burner. Chicago Journalism Review, 4 (Fall) : 11-12

Melucci, A. (1985). The symbolic challenge of contemporary social movements. Social Research 52(4): 789-816

Molotch, H. (1988). Media and movements. In Zald, M. \& McCarthy, J. (Eds.), The Dynamics of Social Movements, Resource Mobilization, Social Control and Tactics (pp. 71-93). Lanham, MD: University Press of America

Morris, M. (1972). Newspapers and the new feminists: Black out as social control. Journalism Quarterly 50 (1): 37-42

North, S. (1970) Reporting the movement. Atlantic Monthly, March: 105-106

NOW Papers (1966-1982) The historical papers of the National Organization for Women are archived at Schlesinger Library for Women in History, Radcliffe College, Cambridge, 
Massachusetts. They are accessible with permission from NOW National Executive Board. See end notes for specific citations.

Offe, C. (1985). New social movements: Challenging the boundaries of institutional politics, Social Research 52(4): 817-868.

Phelan, S. (1989). Identity politics. Lesbian feminism and the limits of community. Philadelphia, PA: Temple University Press

Ryan, C. (1991). Prime-time activism: Media strategies for grassroots organizing. Boston: South End Press

Robertson, N, (1992). The girls in the balcony. Women, men and the New York Times. New York: Random House

Schlesinger, P. (1990). Rethinking the sociology of journalism: Source strategies and the limits of media-centrism. In Ferguson, M. (Ed.), Public communication: New imperatives (pp. 61-83). London: Sage

Simpson, P. (1979). Covering the women's movement. Nieman Reports Summer: 19-23

Touraine, A. (1985). An introduction to the study of social movements. Social Research 52(4): 749-787.

Tuchman, G. (1978). Making news: A study in the construction of reality. New York: Free Press 
Van Dijk, T. (1988). News as discourse. Hillsdale, New Jersey: Lawrence Erlbaum Associates

Van Zoonen, L. (1992). The women's movement and the media: Constructing a public identity. European Journal of Communication 7 (4): 453-476.

Van Zoonen, L.(In press) . "A dance of death: New social movements and mass media," pp. 201-222. In Paletz, D. (Ed.) Political communication in action. States, institutions, movements, audiences. Cresskill, NJ: Hampton Press 


\section{NOTES}

1 The historical papers of the National Organization for Women are archived at the Schlesinger Library for Women in History, Radcliffe College, Cambridge, Massachusetts.

${ }^{2}$ Gitlin's (1980) study does present SDS leaders as quite reflexive and subtle in their political analyses, and perhaps over time their media strategies and media representation would have developed differently. However, his conclusion is clear in that he asserts that news media will always play a hegemonic role and will always trivialize "real" opposition.

${ }^{3}$ Ryan describes the day-to-day strategic communication practices, or "framing contests" of a Boston labor union, Local 26, and a citizen action group, the New Bedford Delegation, and concludes that though the relationship is a struggle, it is not a closed or hopeless one.

${ }^{4}$ As Hall (1977) has note, one of the key aspects of hegemonic processes is that they are never stable; they always have to be maintained strategically by dominant discourses and actors. This also means that they are always open to challenge. Giddens' idea of reflexive monitoring and use of constraints as resources (1984) offers a framework for understanding how strategic counter-hegemonic activities might be understood.

${ }^{5}$ Goffman's (1966, p. 137) conceptualization of strategic interaction involves the formation of a subsequent interaction based on information gained from the previous one, which is to say that agents learn from responses to their past communications and encode that information into their next strategic "move. "Giddens (1984) has used this idea of reflexive monitoring to inform theories of social formation and change. Habermas (1984) draws on ideas of strategic interaction in contrast to "communicative action," in which the goal is not strategic control but understanding. 
${ }^{6}$ Other writers on the movement have labeled the breakdown as one between "liberal" and "radical" groups, but I have used Freeman's classification because it is more descriptive and less pejorative. As she points out, using liberal vs. radical labels for the movement can be largely a matter of the writer's opinion, and may have little to do with how the groups would identify themselves. NOW, for example, widely cited as "liberal" in the liberal-radical dichotomy see themselves as "militants," even though often that militance is tempered by pragmatism. As Freeman notes, then and now, differences between feminist groups are not easily captured by traditional left-right labels. Many feminist groups want radical changes in the relationships between the sexes, economically, socially and politically, but have different strategic plans for how these can be brought about.

${ }^{7}$ NOW (1966) Statement of Purpose. NOW papers, Schlesinger Library for Women in History, Radcliffe College, Cambridge, Massachusetts.

${ }^{8}$ NOW, (1968). Public Relations Guidelines for NOW Members and Chapters. NOW Collection at Schlesinger Library for Women in History, Radcliffe College, Cambridge, Mass.

${ }^{9}$ NOW (1971). Press Handbook, written by Lucy Komisar, revised by Toni Carabillo, NOW vice-presidents for Public Relations. NOW Collection at Schlesinger Library.

10 NOW, (1971), p. 5

${ }^{11}$ NOW, (1971), p. 10

12 Papers in the NOW Public Information Office document a short lived attempt by NOW to produce their own "women's issue" press mailing on a regular basis, called the NOW News Service. Although feedback from editors around the country was 
positive, and much of the material was used by small papers, NOW had to discontinue the service due to resource issues and shifts in organizational priorities.

${ }^{13}$ The press packages represented considerable investment of time, skills and resources. The "NOW Right to Choose Kit" from 1974, for example, included an analysis of groups for and against abortion rights; an analysis of the 93rd congress positions on the issue; background on abortion legislation and cases; contact numbers of NOW's task force members on abortion; information from Planned Parenthood (another advocacy organization) and so on. In later years the press packs became even more sophisticated with an ERA pack in 1980 that was said to be widely used by reporters all over the country.

${ }^{14}$ And in fact it was many of these same reporters who, with NOW's help, sued their employer The New York Times for sexual discrimination in hiring and promotion in the mid 1970s. See Robertson (1992) for an account of this struggle.

${ }^{15}$ Papers of the Public Information Office 1973-1975. NOW Collection, Schlesinger Library. Such analysis is labor and organizationally intensive and is unlikely to be undertaken regularly by any but the richest sources, however.

16 See for example Ericson et al.'s (1989) description of how bureaucracies control their information exchanges with media workers.

${ }^{17}$ NOW (1968), p. 2

${ }^{18}$ For example, NOW these days is widely seen as a pro-lesbian organization, and fighting discrimination on the basis of sexual identity is one its main tasks.

19 There have been some reports of news coverage of the movement, but they conflict on how the movement was covered. Morris (1972), for example, says that the movement was subject to a media "blackout." Hole and Levine (1972) suggest that negative coverage of the movement was rife and that early movement activities were 
ridiculed. Freeman (1975) hints at a distinction between the coverage of the younger and older branches, but does not really elaborate. To date there has not been an extensive, systematic study of the coverage of the movement over time.

20 There has been some speculation, for example (though less empirical demonstration), that feminists have had effects on news discourse. The routine use of such terms and categories as "sexism," "sexual harassment," "pro-choice," and even "women's issues," with all its attendant problems, for example, can be seen to be the results of ongoing strategic communication by feminists that have changed news categories. 